\title{
Is There Really 'Another' Counterexample to the Secularization Thesis? Religious Dynamics in Italy Between 1910 and 2013
}

\author{
Ettore Scappini ${ }^{1}$ (D)
}

Received: 29 April 2021 / Accepted: 24 September 2021 / Published online: 16 October 2021

(C) The Author(s) 2021

\begin{abstract}
Background Among the modern Western countries where the issue of religiosity has been studied, the United States and Italy offer the only examples of empirically verified periods when religious practice was consolidated or even revived to some extent. A recent study, however, shows that the nature of religious exceptionalism in the United States does not constitute a real counterexample. This leaves Italy as the only country that might provide evidence of the falseness of the assumption that the secularization process is inescapable.

Purpose This study seeks to enhance our knowledge about the case of Italy, where the many surveys conducted over the years have produced a wide variety of often divergent results, prompting a fervent debate among scholars. Several authors argue that the level of participation remained almost constant from 1980 to 1990. Others, on the contrary, claim that the level of participation increased between 1980 and 2000. This paper contributes to this path of study, aiming to shed light on the development of religiosity in Italy between 1910 and 2013.

Methods Different data sets-time use surveys, 'stylized surveys', direct surveys and other kind of data - and an innovative method will be used to develop the reasoning and trace the trend of secularization.

Results As will be shown, there are discontinuities in the pattern of religious practice over time. These fractures were due to attrition caused in turn by factors related to economic phenomena like migration and political/ideological subcultures, which temporarily changed the level of religious practice and, at least for a time, counterbalanced the long-term trend away from religious practice.

Conclusions and Implications The trends presented suggest that secularization in Italy developed without any discontinuity, leading to confirmation that modernization and religious action 'counteracted' each other in an extremely regular manner. Therefore, according to the current state of knowledge, no documented modern Western country constitutes a counterexample to the secularization thesis. It can thus be claimed that modernization and secularization are inextricably linked processes.
\end{abstract}

Extended author information available on the last page of the article 
Keywords Birth-cohort effect $\cdot$ Period effect $\cdot$ Religious practice $\cdot$ Religious

socialization $\cdot$ Secularization $\cdot$ Modernization $\cdot$ Time use

\section{Background}

Virtually every discussion about the process of religion losing social significance in modern Western countries features the contrasting views of those who support and dispute the inevitability of the phenomenon. While the arguments supporting both theses are generally based on empirical evidence, it is more difficult to explain the causes of events, and any interpretations are often based on information that is not shared.

The first of the two opposing groups of scholars consists of those who directly or indirectly support the inexorable nature of secularization and believe in a future society where religion will play a marginal role at best (Wilson 1976; Bruce 2011a; Voas and Chaves 2016). In contrast, the second group believes that secularization is not inevitable and suggests that any variation is cyclical in nature (Stark and Bainbridge 1980; Iannaccone 1991; Finke and Stark 1992). To prove the validity of their assertions, the first group frequently presents data indicating that the importance of religion is in decline, often with a strictly monotonic trend, while the second counters with situations where this is not the case, highlighting circumstances where religious practice has been consolidated or even forms of religious revival.

In an attempt to explain the evolution of religion, scholars attribute the secularization process to a clash between two opposing forces: modernization and religious action. The former is understood in the broadest sense of the term and refers to a complex blend of factors such as social differentiation, societalization and rationalization (Wallis and Bruce 1992, p. 11; Dobbelaere 2004; Martin 2005, p. 17), aspects that may not all be present in any given context (Bruce 2011a, p. 26). The latter, on the other hand, concerns action implemented by the Church to obtain the consent of individuals to follow religious tenets (Wilson 1976; Stark and Iannaccone 1994).

Given the above, it should be relatively easy to identify and explain any changes in current trends. However, documented variations in the development of this process are both quite rare and difficult to measure (Voas and Chaves 2016; Scappini 2018). Indeed, as is known, the size of the error and the erratic nature of studies on religious behaviour prevent a clear, unambiguous reading of what has happened.

In the studies conducted in modern Western countries (Voas and Crockett 2005; Wolf 2008; Voas 2009), the USA is seemingly the only nation besides Italy where it can be said with reasonable certainty that secularization temporarily weakened in the early 1980s. Indeed, the process almost came to a halt there (Chaves 1989) due to a change in the religious action of the different Churches (Wilson 1976). A recent study, however, shows that the nature of religious exceptionalism in the United States does not constitute a real counterexample (Voas and Chaves 2016). This leaves Italy as the only country that might provide evidence of the falseness of the assumption that the secularization process is inescapable.

As will be seen, the Italian case shares some similarities with the American situation, as discontinuities were found from the 1960s to the 1980s, prompting a fervent 
debate among scholars about the causes. Unlike in the USA, however, there have been no significant changes in religious action in Italy over the past century and a half.

With regard to the latter aspect, it seems that the principles of Catholic intransigentism, based on the faithful's submission to the Church and the repudiation of modernism, were guiding elements for the Papacy in defining its social doctrine from the mid-1800s to the early 1970s. It was a position that only abated, perhaps, with the pontificate of John Paul II (Verucci 1976; Menozzi 1993). Furthermore, it is worth remembering that there was a religious monopoly in Italy until the end of the twentieth century, with Catholicism as the only widespread religion. It can thus be observed that the religious action of the Italian Catholic Church remained unchanged from the second half of the 1800s until at least the early 1990s.

With regard to modernization, the analysis of such a complex phenomenon and the variability of some of its major defining elements over the course of the twentieth century would deviate from the established goal. As will be seen, though, the effects of interrelating these aspects lead to a surprisingly consistent result with extremely constant expansion of secularization over time.

There is therefore reason to argue that religious action in twentieth-century Italy was constant, and that modernization expanded in a uniform manner. These assumptions are important, firstly because it will thus be possible to ignore the effect of two of the major factors involved in the process, significantly simplifying the subsequent discussion, and secondly because the search for an explanation will be broadened. ${ }^{1}$

This paper aims to shed light on the development of the level of religiosity in Italy between 1910 and 2013. Our analyses will show that despite the extreme regularity of the development of the secularization process, there are discontinuities in the pattern of religious practice over time. These fractures are transitory and due to attrition caused by specific factors connected with temporary economic and political phenomena. As this study will show, these discontinuities have little to do with the process of secularization, which did not deviate from its 'natural trend'.

\footnotetext{
${ }^{1}$ The invariance of religious action is a simplification made necessary to be able to carry out this study. It is known, however, that there are differences between the various areas of Italy in terms of both the development of secularization (Cartocci 1994; see also Cartocci and Vanelli 2015) and religious offer. Diotallevi showed for example that, from the first few decades of the twentieth century onwards, religious action achieved better results in the North than in the South, despite the fact that the process of modernization was more intense in the North. This result is due to the fact that there is '... a link between the dynamics and quality of the religious offer and the dynamics and quality of the religious demand.' (1999, p. 9). The phenomena under discussion are nevertheless regular; they change slowly and at most slow down the secularization process. There is therefore no reason to believe that these territorial differences might have modified the overall trend of the religious phenomena analysed in this study.
} 


\section{Methods}

\section{The Data}

A wide variety of data were used to develop the reasoning (see Table 1 in the Appendix). ${ }^{2}$ It is therefore not possible to offer an in-depth presentation of all the surveys, many of which are already known. Some observations on the lesser-known ones are included and the most distinctive aspects are highlighted when necessary.

The datasets used to trace the development of secularization belonged to three groups. ${ }^{3}$

The first consisted of time use surveys - specified by the acronym TUSwhich use an indirect method of measurement. In this case, Mass attendance was measured by identifying it among the activities logged in a diary kept by an individual for a specific day of the year. The Saturday afternoon and Sunday attendance figures for 52 weeks were added up to obtain the average of those who attend church on an annual basis. In more formal terms, a value $(x=1.0)$ was assigned to each of the $N$ interviewees depending on whether or not they attended Mass on Saturday $(S)$ or Sunday $(D) . N_{j}, x_{j}\{j=s, d\}$ was then used for the ratio $P=\sum_{1, s}^{N_{s}} x_{i, s} / N_{s}+\sum_{1, d}^{N_{d}} x_{i, d} / N_{d}$, regarding the mean proportion of respondents that attended a service during the year. The term presence at church was used to refer to the index $P$ (Rossi and Scappini 2014).

The second group were referred to as 'standardized surveys' and always used an indirect method. They were based on a questionnaire in which there was an item about the frequency of Mass attendance. Two selection criteria were used to guide the choice of surveys. The first of these was repeated cross-sectional surveys with public access to the data, on the basis of which four repeated cross-sectional studies were selected: ADL, EUB, EVS, ITANES. The second criterion was to consider the oldest available surveys, leading to the selection of six cross-sectional studies: CIV, MIS, PAN, and three from Doxa.

The indicator used in the standardized surveys was not consistent with its TUS equivalent. In order to make the information comparable in a similar way to the work carried out by various authors (Presser and Stinson 1998; Gershuny 2003), a conversion had to be performed. In formal terms, this involved the addition of the products of the number of people $f_{x}$ for each typical attendance frequency, ${ }^{4}$ codified

\footnotetext{
${ }^{2}$ For further details on the surveys used, here follow some bibliographical references. For Time Use Surveys, see Rossi and Scappini (2012) who only used the years 1988 and 2003. However, the method of collection and the encoding have not changed since 2003. For Civic Culture Studies, see Almond and Verba (1974), Doxa (1956, 1962, 1973), Misura (Carli 1960), Panorama (Burgalassi 1967). For the remaining surveys see Vezzoni and Biolcati-Rinaldi (2015).

3 Other data not from surveys were also used, like the extent of internal migration from 1902-new members due to change in residence-and census data from 1861 onwards (Istat. www.istat.it), the fraction of CGL trade union members from 1906, renamed CGIL in 1944 (Giacinto 1995; Horowitz 1963, pp. 71, 75, 196, 208; Romagnoli 1980: 193 et seq.) and the fraction of votes for left-wing parties from 1946 onwards (Istituto Cattaneo. www.cattaneo.org).

4 The frequency values used are those specified in the response mode if the indication is unique (e.g. once per month $=12$ ), the intermediate value if the indication is a range (e.g. 1-3 times per month $=(12+36) / 2=24)$.
} 
in the questionnaire with $x_{c}\{c=a, b, \ldots, C\}$, and usually pertaining to a yearthereby identifying the positive events-dividing the result by the number of possible events $-N \cdot 52$. In concise form, $P=\sum_{c=a}^{C} f_{x_{c}} \cdot x_{c} /(N \cdot 52)$.

The third dataset included direct surveys. In this case, presence at church was measured by selecting a certain number of parishes and counting their congregations on Saturdays and Sundays $(p)$, comparing the total value obtained to the reference population- $P=p / N .^{5}$ It should be noted that is extremely difficult to carry out large-scale surveys of this type in which the sample assumptions are respected and the demographic information on churchgoers is often almost non-existent or extremely approximate (Hadaway et al. 1993). The only attempts made in Italy at a national level were those conducted in 1960 by the periodical Vita (Burgalassi 1960, 1967, p. 25) and a study administered from 1951 to 1966 by Burgalassi (1968)_ acronym BUR. ${ }^{6}$

As the research used surveys with such different characteristics, one problem that arose was varying degrees of reliability in measuring presence at church.

While diaries can be used to carry out extremely accurate studies on the average intensity with which a given activity is performed, standardized surveys provide very imprecise information (Kan and Pudney 2008; Scappini 2021). This problem is exacerbated when the question refers to a moral dimension like religious behaviour (Presser and Stinson 1998; Hadaway and Marler 2005; Rossi and Scappini 2014). Finally, direct measurement should provide even more precise information than the diary method by eliminating distortion due to self-selection of the sample (Ellison 1992; Rossi and Scappini 2012) and possible ambiguity in the reading of the reported activities.

To summarize, although there is sufficient information for the research, there are also some problems. Standardized surveys typically provide biased estimates, but they are the most common type and are distributed over a long-term period of time. The TUS data, on the other hand, are much more accurate but have only been available since 1988. Finally, direct surveys cannot be ignored: they convey the idea that the level of presence at church in the early 1960s was much lower than the estimates generated by the standardized surveys.

\section{Some Important Concepts}

A new concept was introduced: socialization of religious practice-hereinafter also simply religious socialization-, which is different from religious practice. Admittedly, there is no great need for yet another definition of religious behaviour.

\footnotetext{
5 The reference population $(N)$ was calculated from the total of the chosen area excluding people 'not required' to attend. This group is estimated, in our case, to be $25 \%$ of the total population (Burgalassi 1967, p. 160).

6 This impressive but relatively little-known study examined behaviour related to $14 \%$ of parishes-3418 surveyed out of 24,410 - representing $13 \%$ of the Italian population-about 7 million individuals (Burgalassi 1968: 11 et seq.). The survey was carried out by representatives who completed forms for each parish by noting the number of attendees at compulsory Masses in a given week and a few other details.
} 
However, for reasons yet to be discussed, although it seems counterintuitive, religious practice and religious socialization can differ significantly. Religious practice was defined as the level of presence at church that was actually found, while religious socialization referred to the natural level of presence at church that would occur in the absence of obstacles defined as attrition.

Before explaining how the two indicators were identified, other concepts need to be introduced to provide a broader framework. As is well known, when there are age-related variations in the level of religious practice, scholars tend towards interpretations based on three factors.

The first is the birth-cohort effect. According to this point of view, religious beliefs are formed at a young age, often in pre-adolescence, and once acquired they remain relatively stable throughout the person's life (Bruce 2011b; Rossi and Scappini 2016; Voas and Chaves 2016). Religious socialization was derived from the birth-cohort effect.

The second factor that can change the level of religious participation is the age effect. From this perspective, religious convictions depend on the current phase of life. For example, it is known that relatively young parents with pre-teen children (6-12 years old) increase their level of religious practice (Stolzenberg et al. 1995), while for elderly people religious participation can be negatively affected by poor health (Bahr 1970). The selection of the age range used-18-74 year-olds-allows us to assume that this type of effect is negligible.

The third factor that can modify the level of religious participation is the socalled period effect. Supporters of this theory believe that the opinions of individuals constantly interact with the values and the dominant social and cultural climate. For example, religious participation can vary in conjunction with major religious events - like after the proclamation of the papal encyclical Humanae Vitae (Hout and Greeley 1987) — or when incredible or miraculous events are recorded.

In this study, the period effect consisted of the different types of attrition that limited the natural propensity to practise religion. Some, like those related to pregnancy or health problems, were always present and were therefore considered marginal and negligible for diachronic analysis. Instead, other types of attrition like internal migration and/or adhesion to specific political subcultures were of considerable importance on the whole, albeit on a temporary basis, and could not be neglected when conducting short- or medium-term analyses.

\section{The Main Indicators and Some Technical Aspects}

Starting from these concepts, different indicators needed to be built to develop the argument. The first one measured the values of religious practice by birth cohort $-P_{c}$. For example, $P_{1920}$ indicated those born in the years $1916-1925$. These values were calculated by selecting only individuals aged 18-74 with Italian citizenship and using the TUS for the most recent cohorts (1910-1990), ${ }^{7}$ while for the older

\footnotetext{
7 For the TUS, this information has only been available since 2008, while for those conducted before that date it is possible to overlook the problem.
} 
ones-1890-1900 - the 1960 CIV survey was referred to. ${ }^{8}$ The values prior to 1890 were then hypothetically estimated by making a linear interpolation and assuming that religious practice was approximately $70 \%$ before 1870 . This value will be justified below.

Once $P_{c}$ was identified, the second indicator could be built, taken from the fraction of the entire population attending church in a given year- $P^{y}$. In this way $P^{y}=\sum_{c} P_{c} \cdot t_{c}^{y}$, where $t_{y, c}$ was the fraction of the population derived from census data that in the year $y$ belonged to birth cohort $c$, under the obvious condition that $\sum_{c} t_{c}^{y}=1.00$.

In the next step, the values relating to religious socialization were determined $-S^{y}$. In practice, this meant:

$$
S^{y}=P^{y} /\left(1-F_{p}^{y}\right)
$$

where $F_{p}^{y}$ was used to denote the level of attrition in the year $y$, regarded as the proportion of those who were not likely to attend church.

$F_{p}^{y}$ was now used to define the period effect due to combined attrition, with religious practice in year $y$ deriving from:

$$
P^{y}=S^{y} \cdot\left(1-F_{p}^{y}\right)
$$

It seems a roundabout method, but this is not the case. It was possible to determine the level of religious socialization because, as will be seen, the TUS were conducted at a time when attrition was almost constant and due to a single main cause: internal migratory phenomena. The consequence was that the calculation of $S^{y}$ did not involve any particular complexity. The discontinuities that were discussed instead occurred at previous times when attrition took shape differently and had a considerable and variable influence.

\section{Results and Discussion}

\section{Preliminary Questions}

Some preliminary questions will now be addressed to help understand what happened in the 1960s and 1990s, and establish when secularization began. The latter information is necessary in order to be able to describe the development of secularization over a longer historical span.

\footnotetext{
${ }^{8}$ The CIV data are from a survey conducted in 1960, with the results of bias due to overestimates and the other forms of attrition in the period. It is felt, however, that these effects are less significant among older subjects. On the other hand, the use of these data is only supplementary to a trend already well identified.
} 


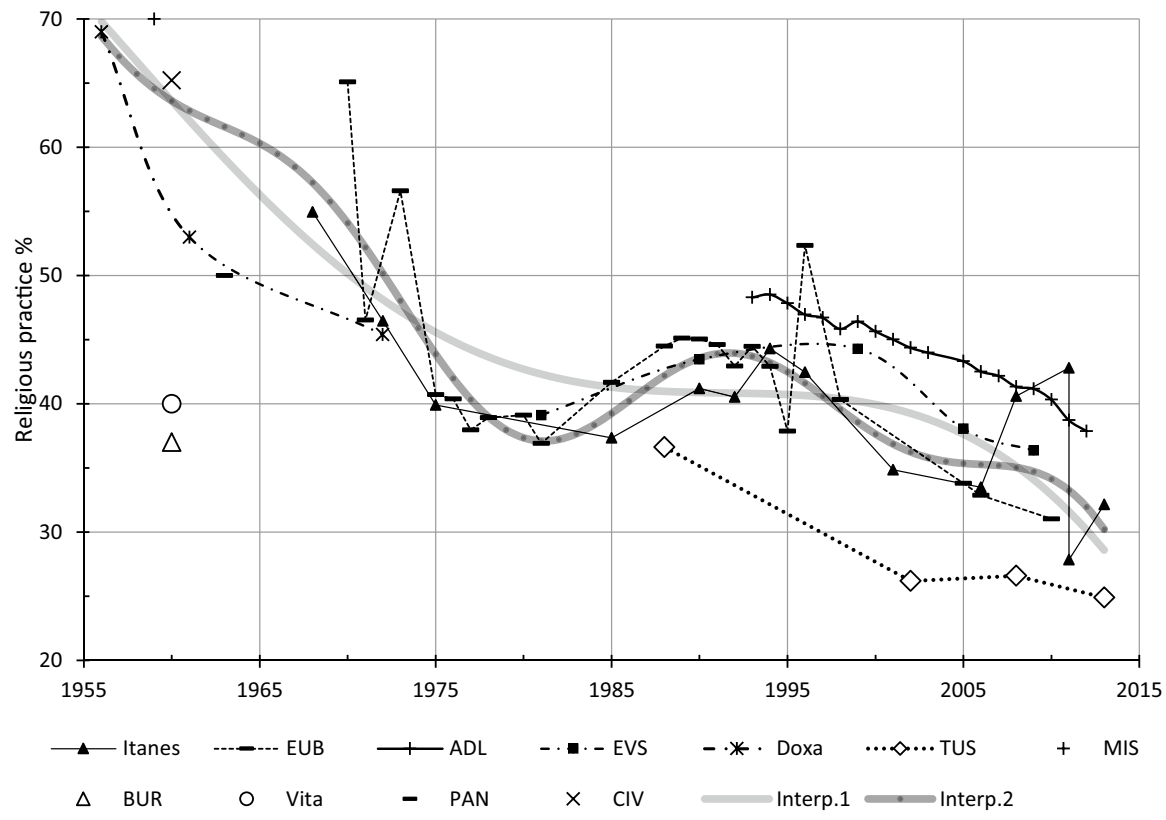

Fig. 1 Pooled dataset of level of religious practice and interpolated trends, years 1956-2013

\section{An Overview of Religious Practice Between 1956 and 2013}

Firstly, an attempt will be made to understand what might have happened between 1956 and 2013. Figure 1 is inevitably disconcerting at first: by comparing both the attendance values found in surveys conducted in the same year and those found in longitudinal studies repeated at close range, it is clear how random the quality of the available information can be. Leaving aside the values of TUS, BUR and Vita for the moment and examining the overall trend observed in the standardized surveys from 1956 to 2013, the uncertainty is reduced, and it is possible to outline one or more paths regarding what may have happened.

To highlight the possible trajectories, the values were interpolated to obtain the two lines identified (interp.1\&2). ${ }^{9}$ Overall, the two curves are very similar, diverging only in the middle. In fact, the historical phase examined is broken down into three parts, with a first and a third phase that are almost identical, where the trend shows a clear decrease in religious practice over time, and a second phase where the two interpolations diverge in both duration and trend. In the first interpolation, it is seen that religious practice decreased slightly or stabilized between 1980/1985 and 1995/2000. On the other hand, in the second interpolation the attendance values

\footnotetext{
9 Interp. 1 is a smoother line with $f(x)=a 1 \cdot \sin (b 1 \cdot x+c 1)+a 2 \cdot \sin (b 2 \cdot x+c 2)$ with $R^{2}=0.73$. Interp. $2 f(x)$ $=a 1 \cdot \sin (b 1 \cdot x+c 1)+a 2 \cdot \sin (b 2 \cdot x+c 2)+a \cdot \sin (b 3 \cdot x+c 3)$ with $R^{2}=0.83$.
} 
Fig. 2 Level of religious practice by birth cohort, EUB.1 (years = 1970-1973), EUB.2 (1975-1978), EUB.3 (19811991)

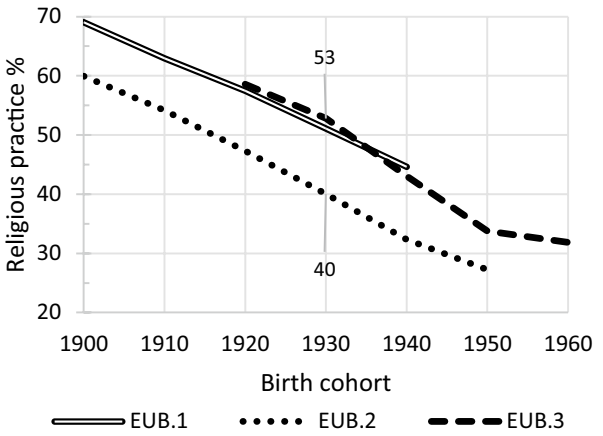

increased between 1980 and 1990/1995, indicating a reversal of the trend or what could be called a religious revival.

Nothing new has been said thus far as these events have already been noted by several authors. Some (Marchisio and Pisati 1999; Vezzoni and Biolcati-Rinaldi 2015) used a wide selection of surveys to reach similar conclusions, arguing that the level of participation remained almost constant from 1980 to 1990 . By contrast, others (Jagodzinski and Dobbelaere 1995; Introvigne and Stark 2005) claimed that the level of participation increased between 1980 and 2000.

Garelli and Ricolfi also reached similar conclusions. While the former stressed that religious practice at the national level was constant and consolidated in the 1970s and 1980s, perhaps even slightly increasing (1996, p. 79), the latter underlined the close relationship between desecularization and the end of the great collective mobilization campaigns promoted by the Italian Communist Party (1988, p. 72).

It could be argued that this is not the right way to deal with the problem. As will be seen, the reading of the data must start from a different point of view. Only then can it be understood which of the two curves is more closely related to events and can an explanation be provided.

\section{From the 1960s to the 1980s: The 'Apparent' Break in the Secularization Process}

The matter will now be analysed in greater depth to try to understand what may have happened during the years in question. Figure 2 shows the trends plotted from the Eurobarometer data on religious practice by birth cohort collected for three groups: EUB.1 (between 1970 and 1973), EUB.2 (1975-1978), and EUB.3 (1981-1991). ${ }^{10}$

EUB. 1 is first compared with EUB.3, considering only the birth cohort from 1920 to 1940 . These subjects were surveyed in different years but have similar levels of religious practice, as the lines practically overlap in the time span considered. In this case, therefore, the expected trend is followed as subjects socialized in the same birth-cohort show similar levels of attendance.

\footnotetext{
10 The EUB cross survey is the only one with continuous data in the period in question. Moreover, for ease of understanding, only unweighted average values are presented for each group.
} 
With regard to the same time span, the focus will now move to the second half of the 1970s (EUB.2). There is clear discontinuity in this case as there is a decrease in attendance of about $10 \%$ among subjects socialized in the same cohorts as the other two groups but surveyed in an intermediate phase.

By just considering EUB.2 and EUB.3, could reference be made to desecularization? Before offering a response, it should be noted that secularization typically develops from the most recent, less religious cohorts, which replace the less recent, more religious ones with the passing of time (Voas and Crockett 2005). Similarly, even possible desecularization should have started by influencing the behaviour of subjects in the younger cohorts.

It follows that a process similar to the one shown in Fig. 2 could have developed if two conditions were met. The first is linked to important events in the early 1980s that may have led to a revival of religious practice. The second is that these events similarly affected those born into different cohorts. With regard to the first condition, it can simply be said that there were seemingly no changes in the religious action of the Church to counter secularization. As for the second condition, it can only be stated that it is highly unlikely that such changes could affect subjects of different ages in the same way.

The full picture will now be examined, providing a different interpretation of what happened. Events at the turn of the 1970s produced a significant decrease in the level of religious practice (from EUB.1 to EUB.2). However, such events or attrition did not affect socialization, and once they weakened (see EUB.2 to EUB.3), religious practice returned to its 'natural course' (EUB.1 and EUB.3). Note that this interpretation, which is believed to be much more convincing, will be supported by other empirical evidence in the study.

Before moving on to the causes of the attrition, there is a final problem to solve, which is to identify, as precisely as possible, when secularization began and the likely level of religious practice by birth cohort in the decades before 1890. This step is necessary in order to be able to ascertain the proportion of the population that attended Mass in the first half of the twentieth century.

\section{The Beginning of the Secularization Process in the Second Half of the 19th Century}

Christianity was deeply rooted in the social fabric of the Ancien Régime. Therefore, even with some differentiation in the various geographical areas and the political divisions of Italy, including the Papacy with its broad temporal power and influence on neighbouring states (Pollard 2008, p. 7), it is easy to think that the behaviour dictated by religious institutions was generally assiduously followed.

From the second half of the eighteenth century onwards, this stability started to fade. The process began with the spread of the Enlightenment and the ideals of the French Revolution, and then developed through the period of alternating political power following the Italian campaign led by Napoleon (1796-1815) to the age of the Restoration and the Italian Risorgimento (1816-1871) (Battelli 1992). 
In addition to this series of events, there was also a significant reduction in the Church's capacity to intervene due to a decrease in both the number of clergy and economic wealth. In fact, towards the middle of the nineteenth century there was an average of one priest for every 250 inhabitants in Italy, rising to 1/327 in 11,881 (Brunetta 1991), ratios much lower than the figure of one for every 50-60 inhabitants in the previous century (Guasco 1997, 84). Concomitant with the reduction in the number of clergymen, there was also a significant drop in ecclesiastical property, falling from $25 \%$ of Italian land at the beginning of the 1800 s to $13 \%$ in 1815 (Atkin and Tallett 2003, p. 81).

While the most significant events of the past, especially those of an institutional nature, are relatively well identified, much less is known about the extent of their influence on the belief system and the religious behaviour of individuals at the time. In a study of this type, however, the loss of importance of religious institutions is not the only significant aspect. Consideration should also be given to variations in these events in different geographical areas, which increases the complexity of the historical framework (Rocca 1992). Furthermore, focus should be placed on the great social calamities that occurred between 1815 and 1847 (Barbagli 2018, chap 1.5), which may have favoured the consolidation of religion especially in rural areas, even with the emergence of new secular processes (Menozzi 1986). Finally, the attitude of bishops, who adapted to modern times in various ways by introducing changes in pastoral action, may have led to a further element of opposition to secularization and/or a religious revival (Menozzi 1992).

In light of this context of highly complex and multi-pronged 'prompts', it should be noted that the majority of the population was still 'rural' in the nineteenth century and lacked ethical and cultural autonomy, at least initially. Scholars are therefore convinced that any stimuli opposing religion were received extremely passively and did not trigger a real process of secularization (Verucci 1976; Battelli 1992).

A more empirical confirmation of the analysis developed here can be obtained from historical studies on delayed baptism, which serve as an indicator of the loss of importance of religious values.

Indeed, until the end of the eighteenth century the salvation of the soul was a family's first goal for a newborn. Typically, the infant was baptized on the day of birth, or the next day at the latest if born in the afternoon. This practice dwindled from around the second half of the nineteenth century onwards, and the objective began to lose importance as other aspects acquired more significance.

Although not all scholars agree on the complete overlap of the postponement of baptism and the beginning of secularization (Gourdon 2006; Minello et al. 2017), the available research shows that the rite cannot have been delayed without changes in the religious consciousness of families (Charpin 1964). It is easy to understand the mechanism underlying this reasoning. At a certain point, Christian sensibilities declined and the concern for an immediate baptism was replaced by the need to organize an appropriate celebration, apprehension for the health of the child due to the risks connected with the baptismal rite, and the emergence of materialistic ideologies contrary to religion, etc. (Burgalassi 1967, p. 108).

With regard to the identification of the historical time when the delay began, the available information is consistent. Burgalassi's research (1967) shows that baptism 
was delayed by up to $48 \mathrm{~h}$ in the early modern period, from 1400 to the second half of the $1800 \mathrm{~s}$. A more systematic survey carried out on a representative number of parishes (500 out of about 24,500) showed that the delay only began to be significant after 1870. Similarly, Gourdon's study of Rome (Gourdon 2006) found that the postponement only started appreciably after 1870 . On the other hand, in their studies of the Italian city of Padua, Minello, Dalla Zuanna and Alfani (2017) found that the delay could already be seen in the second decade of the 1800 s, specifying moreover that the phenomenon started among the urban upper classes.

In summary, the available information leads to the following considerations. It is likely that secularisation began with Napoleon's descent into Italy at the end of the eighteenth century. There are no definite elements to assess the impact that political changes may have had on religious practice, but it is likely that any variations were not significant. Moreover, the years of the Restoration saw the Church regain the level of power it had before the invasion, especially in the South and in the Papal States. It can therefore be assumed that initially secularisation developed very slowly and began in the early 1800 s, especially in the urban areas of the North, and that the phenomenon only had a widespread and gradual increase throughout the peninsula from 1870 onwards.

The initial slow development of secularisation allows us to assume that the values measured by birth cohort at the end of the nineteenth century-see below in Fig. 6-were not very different from those for the previous decades $\left(P^{1890}=67 \%\right)$. It therefore seems reasonable to place the level of religious practice in the second half of the 1800s at approximately $70 \%$, which corresponds to a value of religious socialization of around $73 \% .^{11}$

Some other important pieces of the puzzle will now be identified and put together.

\section{Identifying and Assembling the Other Pieces of the Puzzle.}

A look at the literature produced in the 1960s and 1980s makes it relatively easy to identify the causes that gave rise to the discontinuities, leading to changes in the misalignment between religious socialization and practice. It is simple to imagine that they could be sought in the same economic and political factors that produced sustained changes in Italian society throughout the twentieth century.

Three measurable aspects related to religious practice have been identified. The first is of a predominantly economic type, namely internal migration, while the other two are of a mainly political/ideological type, namely membership of left-wing trade unions_CGL or CGIL_-and/or voting for a left-wing party (the Communist Party or another party on the far left). Various forms of decrease in religious practice were associated with the increase in each of these factors in certain historical phases.

\footnotetext{
11 Calculated in the following way: $73 \approx 70 /(1-0.045)$ see $(1)$. In this, $4.5 \%$ is the value of $F_{p}^{y}$ derived from the average level of migration in the years 1990-2010. In practice, however, the level of religious socialization should be even higher, probably by a few percentage points, as the level of religious practice identified by the TUS is also subject to the limitations already shown with those not required to attend and not considered among the sources of attrition.
} 
Fig. 3 Level of religious practice by length of migration and Vote Left or Union, Itanes 1972

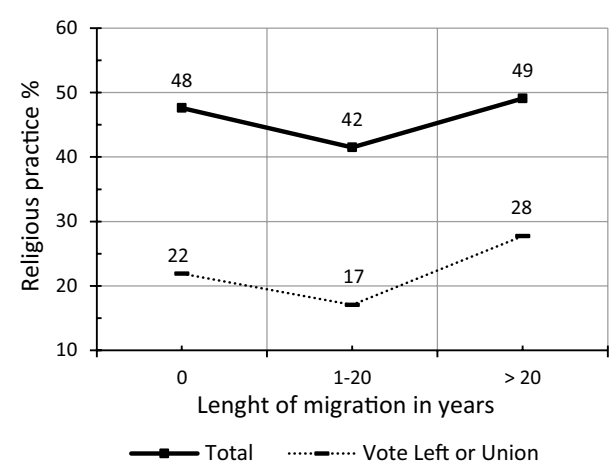

\section{Internal Migration and Religious Behaviour}

The first factor to be considered is migration. On this subject, the available literature has, in different ways, underscored the negative relationship between internal migration-hereinafter just migration - phenomena and religious practice (Jitodai 1964; Welch and Baltzell 1984; Bibby 1997). From the few studies undertaken, the Italian situation seems to fall within the norm.

With regard to the great migratory flows that characterized Italy during the economic boom from the 1950s to the 1970s (Bonifazi and Heins 2000), it has been observed that in most cases of migration a change of residence causes the uprooting of individuals, who are therefore no longer subject to the social forces of their original environment that would push them towards conformity (Grumelli 1965; Burgalassi and Scarpati 1966). Together with the great difficulties in integrating into the indigenous society, this reduces immigrants' chances of becoming part of local life, which in turn has an impact on their level of religious practice (Gamerro 1960). Burgalassi and Scarpati (1966; see also Burgalassi 1967) found that typically this abandonment is not definitive and that there is a return over time. The authors estimated that the interruption is remedied in no more than 20-25 years.

While the studies discussed with regard to Italy have a fragmentary empirical basis, more recent data allow the truthfulness of these statements to be verified. The 1972 ITANES survey can be used to confirm that migration only temporarily reduces the level of religious practice. Indeed, Fig. 3 shows that the level of Mass attendance among migrants (42\%) is around 6/7\% lower than the figures for those who have not changed their municipality $(48 \%)$ of residence and those who migrated more than twenty years previously (49\%). This would mean a reduction of approximately $10 \%$ in relative terms as the level of presence at church was nearly $50 \%$ in 1972 according to these data.

However, information on migration status is not available in the TUS. Even if it were, it would be related to recent years and therefore of little use. The level of attrition was therefore calculated from the migration statistics, which are available from 1902 onwards. To make the measured values compatible with the 1972 ITANES data, it is assumed that on average roughly one out of every ten migrants takes 
20 years to return to his or her pre-migration situation. Then for the contribution of $F_{m}^{y}$ it was assumed that:

$$
F_{m}^{y}=\sum_{i=y-20}^{y} \frac{n_{m}^{i}}{N_{\text {all }}^{Y}} \cdot \frac{1}{10}
$$

The suffix $m$ indicates the subject of migrations, with $n_{m}^{i}$ the number of migrants who have changed municipality of residence in year $i$ and $N_{\text {all }}^{Y}$ the total census population.

\section{The Communist Subculture}

The discussion about the outcome of the ideological clash between the Catholic Church and left-wing parties or trade unions is complex, as well as problematic. In addition, however broad the scientific literature on the subject may be, its orientation does not fully account for what actually happened between the 1960s and 1980s.

The debate on the political repercussions of competition between opposing ideologies and subcultures originates from the seminal idea of Lipset and Rokkan (1967). They pointed out that it is the result of the capacity of a given party to win consensus by redefining and conveying or integrating the variety of individual interests along certain lines of demarcation called cleavages. Two such cleavages were considered critical and persistent in most West European countries: religion (state-church) and social class (owner-worker) (Galli 1968: 39 et seq.; Thomassen 2005, p. 9).

Specifically, the studies in Italy show that the political leanings of those bound to the Catholic religion are primarily oriented towards the party that embodies the culture's principal values, i.e. the DC (Christian Democratic Party), while workers primarily vote for parties that reflect a communist subculture (extreme left parties, the Communist Party and also, initially, the Socialist party) (Mannheimer and Sani 1987; Biorcio 2003; Diamanti and Ceccarini 2007; Ignazi and Wellhofer 2013).

Most research also shows that the two fractures are mutually exclusive. Naturally, some exceptions were observed, especially in the more recently industrialized areas, like in the small municipalities of the North-East where the Church managed to maintain a certain influence over voting, even among the working class (Barnes 1974; Sani and Segatti, 2002), while at the same time the left-wing parties also gained ground in other professional categories (Sani 2006). However, it was generally found that being both Catholic and Communist was neither simple nor frequent.

This incompatibility did not remain stable, though, and changed considerably over time in terms of both importance and magnitude.

At the beginning of the twentieth century, parish priests were aware that workers, especially members of trade unions, frequently abandoned religious practice with worrying frequency (Burgalassi 1967: 16 et seq.; Guasco 1986 chap 7). On the other 
Fig. 4 Level of religious practice by years and Vote Left or Union, Itanes 1968-2001

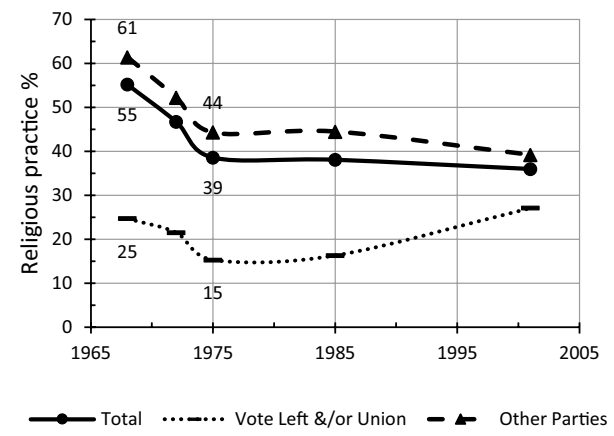

hand, the Marxist ideologies that conditioned the party, especially in the first half of the twentieth century, left little space for coexistence with religion (Zunino 1975: 96 et seq.).

The complex, fluctuating level of conflict among Catholic institutions already present in the 1920s evolved into an ever-increasing radicalization of the clash (Zunino 1975: 351 et seq.), culminating in Pope Pius XII's 'Decree Against Communism' in 1949. This officially established the doctrinal incompatibility of being both Catholic and Communist (Ruggieri 2011).

Research carried out in urban areas at the end of the 1970s (Kertzer 1980) confirmed that adherence to party activities was strongly incompatible with regular participation in religious activities, although this irreconcilability was less cogent in rural areas (Faenza 1959). Finally, a 1985 study (Mannheimer and Sani 1987) showed that only $8 \%$ of respondents were able to reconcile the two ideologies.

In the early 1990s, the clash between the two subcultures declined in importance (Segatti 1999; Sani and Segatti 2002; Bellucci and Heath 2012). From that moment on, individuals no longer felt there was a problem with being both religious and left-wing.

While the studies discussed for the Italian situation have a fragmentary empirical basis, survey data make it possible to verify these statements. Using the ITANES data-see Fig. 4-the course of religious practice was plotted, broken down into subgroups.

As can be seen, two aspects can be highlighted by separating those who voted for left-wing parties or are members of a trade union (Vote Left or Union) and comparing them with the entire sample. The first is a strong reduction in the degree of religious practice among those who associate with or are involved in left-wing activities. The second is that the influence of involvement is not stable but varies over time: it hit a peak in the first half of the 1970s and returned to its original level after 2000.

In other words, in certain historical moments and in variable terms, even temporary affiliation with a left-wing party and/or the CGIL-considered the communist trade union (Romagnoli and Rossi 1980, p. 95)—could induce changes in religious behaviour. 


\section{Religious Behaviour and the Communist Subculture}

Following a similar strategy to the one used above, the level of religious practice was calculated by subtracting the effects of union membership and voting for leftwing parties from religious socialization and the effect of migration.

Then, for the attrition due to trade union membership_-data available from 1906-it was assumed that:

$$
F_{u}^{y}=\left(1-F_{m}^{y}\right) \cdot \frac{n_{u}^{y}}{N_{18-74}^{Y}}
$$

where the suffix $u$ indicated a trade union, $n_{u}^{y}$ was the number of members and $N_{18-74}^{Y}$ was the census population aged between 18 and 74. In the same way, the attrition due to voting for left-wing parties was then calculated-a figure available from 1946 onwards and which included the Communist Party or another far-left party. In this case, it was assumed that:

$$
F_{g}^{y}=\left(1-F_{m}^{y}-F_{u}^{y}\right) \cdot \frac{n_{g}^{y}}{N_{18-74}^{Y}}
$$

where the suffix $g$ indicated elections and $n_{g}^{y}$ was the number of votes for left-wing parties. The total sum of the sources of attrition, or the overall period effect, was thus equal to:

$$
F_{p}^{y}=F_{m}^{y}+F_{u}^{y}+F_{g}^{y}
$$

Note that by calculating the effects in this way, it was also supposed that there was a partial overlap of the sources of attrition. As will be seen below, this was a necessary stratagem to make TUS estimates compatible with BUR and Vita values.

It can now be established when, in the time span from the second half of the 1960 s to the second half of the 1980 s, the effect of $F_{p}^{y}$ reached its peak value, or the year with the greatest difference between socialization and religious practice. Using the ITANES data, the year can be identified as 1975, while the EUB data show a sequence of values of religious practice that are extremely similar and close to the minimum, between 1977 and 1981-see Fig. 1. It should be noted that the contribution due to migration- $F_{m}^{y}$-reached its maximum value between 1965 and 1970 while the political contribution $-F_{g}^{y}$-peaked in 1976 (see Fig. 5). As a first approximation and for the sake of simplicity, it was therefore assumed that religious practice reached its minimum value in 1975 .

A few aspects will now be clarified. The effect of the left-wing subculture on religious practice can be divided into two further influences. The first of these is the increase, until at least 1975, in the number of subjects connected to the left-wing subculture (see Fig. 5). The second is the radicalisation of political conflict and its repercussions on religious behaviour. In other words, the level of religious practice decreased further during the period of radicalisation of the conflict also among those involved in the left-wing subculture. 
Fig. 5 Trends of some structural variables over time, years 1902-2013

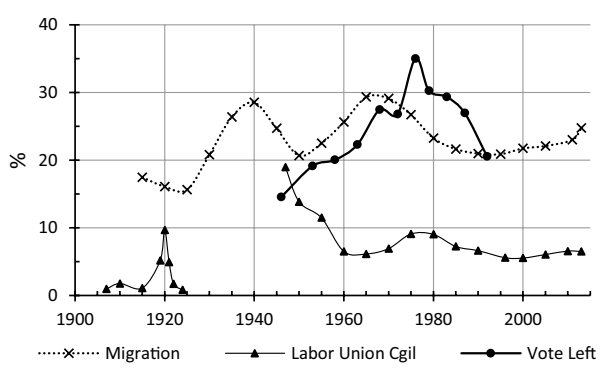

It should be reiterated that the framework outlined here has been simplified, inasmuch as it was assumed firstly that there was no religious practice among those on the left $^{12}$ and secondly that there was a linear relationship between the left-wing subculture and the overall level of practice.

It can now be ascertained whether these approximations led to significant bias. With regard to the first aspect, as will be seen, the level of religious practice was well approximated as the estimated values for the 1960s almost coincide or are slightly higher than the extremely reliable data in the BUR and Vita surveys. ${ }^{13}$ Therefore, the set of assumptions adopted led to a good level of approximation. With regard to the second aspect, no corrections were introduced as it was felt that a more complex calculation would not produce any more information. In other words, the 'rift' was identified without considering the radicalisation of the conflict. ${ }^{14}$ Moreover, there is no reason to believe that the overall trend is very different from the one which was discussed.

\section{Assembling the Pieces of the Puzzle}

The pieces of the puzzle will now be assembled. The first step was estimating the level of religious practice by birth cohort $\left(P_{c}\right)$ identifying the trend from 1870 to 1990 - see Cohort Hypothetic, Cohort CIV and Cohort TUS values in Fig. 6. Based on this information, the level of religious socialization $\left(S^{y}\right)$ was estimated-see Pop Socialization Hypothetic and Pop Socialization.

Starting from the estimate of religious socialization, the values of religious practice were calculated by adding the three forms of attrition discussed-Pop Church $\left(P^{y}\right)$. For example, see Eq. (2), in 1975 religious practice $\left(P^{1975}\right)$ was obtained by subtracting the forms of attrition from Pop Socialization $\left(S^{1975}=49 \%\right)$. Attrition was calculated in terms of migratory effect $F_{m}^{1975}=5 \%$, trade union effect $F_{u}^{1975}=9 \%$

\footnotetext{
12 Even considering the fact that standardized surveys significantly overestimate the levels of religious practice (see also Rossi and Scappini 2012), there is probably a small percentage of those in the left-wing subculture who attend Mass. The partial overlap of the sources of attrition was also useful for correcting this type of bias.

13 As Fig. 6, below, shows, the values are: $P^{1960}=40 \%, \mathrm{BUR}=37 \%$ and Vita $=40 \%$.

14 In the period of the radicalisation of the conflict ('68/'75), which is not examined in this study, the change in religious practice also affected those who were not part of the left-wing subculture. The latter dropped from 61 to $44 \%$ (ratio .72, Fig. 4). This figure is significant but much lower than those who stated they were involved in it (ratio .60). It is totally feasible, however, that the political conflict also involved some of those who did not explicitly declare their left-wing affiliation.
} 


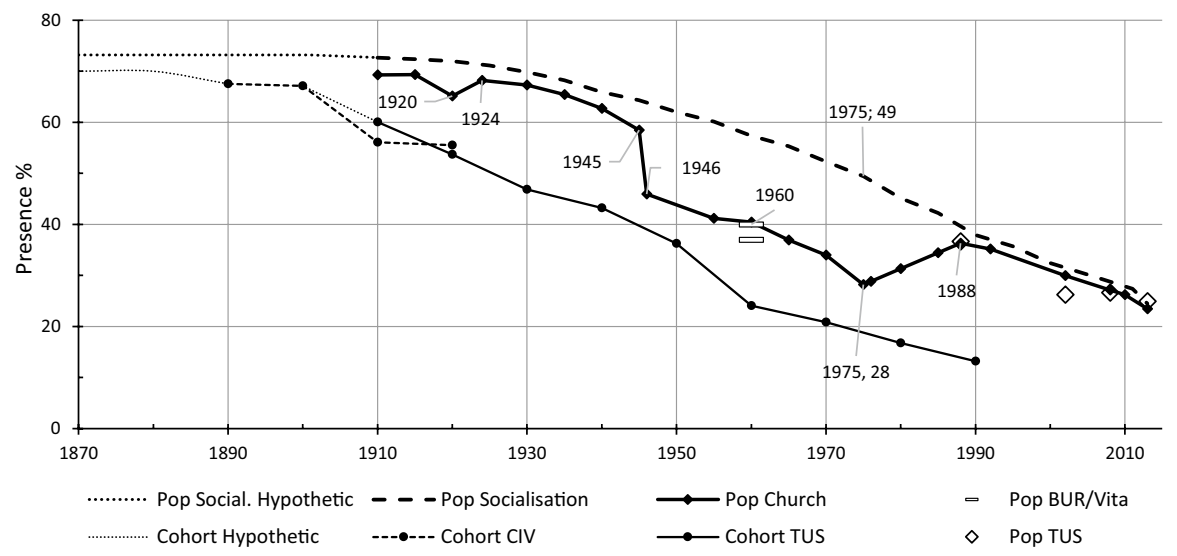

Fig. 6 The overall evolution of religious behaviour, years 1870-2013

and political party effect $F_{g}^{1975}=29 \%$. Consequently, the religious practice of the population in 1975 was $28 \%=49 \cdot(1-0.05-0.09-0.29)$.

The sources of attrition added were firstly those due to migratory phenomena with data available since 1902, then those related to membership of trade unions since 1906 and finally those deriving from voting since 1946. It is therefore probable that until 1945 the deviation identified between socialization and religious practice is lower than the actual value since the measure relating to association with the leftwing subculture is only partial.

The definition of the trends from 1975 to 1988 reveals another problem, namely that there is no way of measuring the loss of importance of the left-wing subculture in influencing religious behaviour. In this case the values from 1975 to 1988 were interpolated on a linear basis. Finally, from 1988 onwards practice values were calculated by assuming that sources of attrition are due only to migratory phenomena.

With the puzzle now complete, the main results will now be discussed.

It should first be noted that the trend of religious socialization-Pop Socialization in Fig. 6-is very regular and strictly monotonic, while the trend of practice is more discontinuous-Pop Church.

The trend of secularization processes associated with religious socialization is clearly monotonic and downward in type. It also follows from this that the interpolations identified-nterp. 1 \& 2-cannot be used for this purpose. The evolution of secularization in Italy is therefore similar to the findings in other studies (Voas 2009; Requena and Stanek 2013; among others). It consists of an initial phase where decline is slow_-which can be placed in the years 1870-1920_, an intermediate phase of loss of importance of religion-which began approximately in the 1920s and still continues today-, and a plausible final phase with inevitably weak decline.

The other indicator to be discussed is religious practice. In this case, the trend is much more uneven. The uniform drop between 1910 and 1920 was interrupted in the early 1920s by a short reversal of the trend. The main reason for this change was the reduction in the number of trade union members, linked to the rise of fascism 
(Horowitz 1963: 165 et seq.; see also Tannenbaum 1972: 54 et seq.). This was exacerbated by the reduction in migratory flows due to the economic downturn (Horowitz 1963: 165 et seq.). This first interruption was followed by a resumption in the decrease of religious practice, even though the level remained similar to the prefascist phase until 1930'.

A second fracture can be seen in the post-war phase. Between 1945 and 1946, with the reconstitution of trade unions and the resumption of political activity, there was an acceleration in the decline in religious practice. This fracture was in all likelihood more diluted over time: it could have begun a few years earlier with the decline of fascism, a phase that cannot be measured because there is a lack of adequate information.

A new cycle emerged in around the 1960s. In the first phase, between the early 1960s and 1975, the trend plummeted, while in the second, between 1975 and the end of the 1980s, there was a reversal of the trend with an upswing in religious practice and an 'apparent' religious revival.

In this case, in the first phase of the cycle the deviation from the natural trend was caused by the concomitant increase in both migration and the leftward shift of the electorate, as well as a partial rise in the number of trade union members. In turn, these events were the product of the economic boom that denoted the modernization of Italy between the 1950s and 1960s (Ascoli 1979) and the ideological 'ferment' that characterized these years (Tarrow 1989). Peaking in around 1975, the concurrent reduction in the phenomena in question brought the development of the secularization process back to its natural trend. From this point of view, albeit in extremely concise form, it is the interpolation interp. 2 that best approximates the trend of religious practice. From the early 1990 s to 2013 , the trend was quite regular, and no further fractures were identified.

\section{Conclusions and Implications}

In summary, the analyses have shown that despite the extreme regularity of the development of religious socialization, there are three discontinuities in the pattern of religious practice: during the fascist period, between 1945 and 1960, and between the 1960s and 1990s. It has been demonstrated that these fractures were transitory and due to attrition caused by specific factors connected with migration and political subculture. Finally, it has been shown that the short-term variations identified have little to do with the process of secularization, which did not deviate from its 'natural trend'.

In conclusion, this article has developed the claim that Italy is not a counterexample to the secularization thesis. As has been demonstrated, secularization developed without any discontinuity, leading to confirmation that modernization and religious action 'counteracted' each other in an extremely regular manner. Therefore, according to the current state of knowledge, no documented modern Western country constitutes a counterexample to the secularization thesis. By implication, it can thus be claimed that modernization and secularization are inextricably linked processes. 


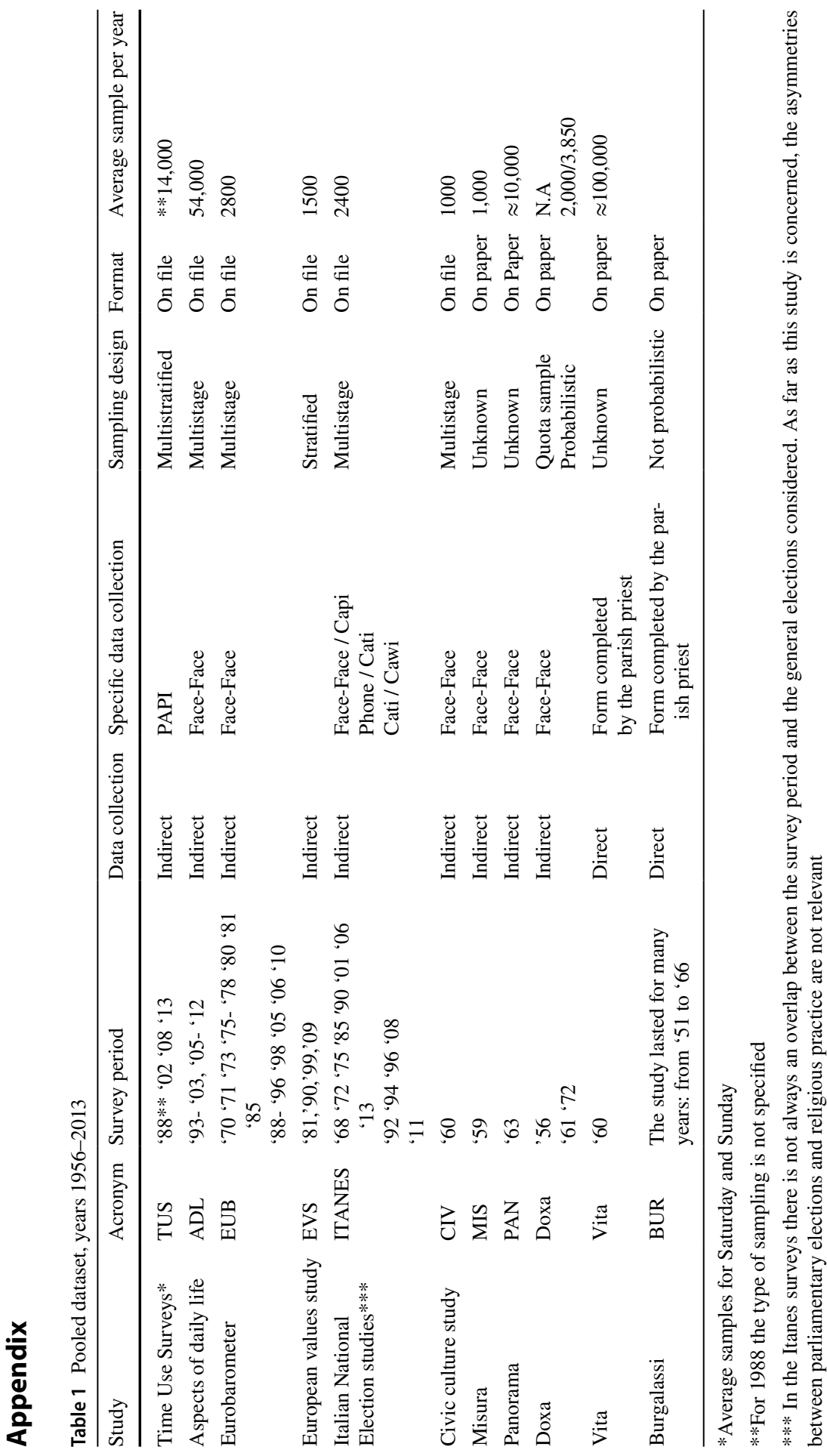


Funding Open access funding provided by Alma Mater Studiorum - Università di Bologna within the CRUI-CARE Agreement.

Open Access This article is licensed under a Creative Commons Attribution 4.0 International License, which permits use, sharing, adaptation, distribution and reproduction in any medium or format, as long as you give appropriate credit to the original author(s) and the source, provide a link to the Creative Commons licence, and indicate if changes were made. The images or other third party material in this article are included in the article's Creative Commons licence, unless indicated otherwise in a credit line to the material. If material is not included in the article's Creative Commons licence and your intended use is not permitted by statutory regulation or exceeds the permitted use, you will need to obtain permission directly from the copyright holder. To view a copy of this licence, visit http://creativecommons.org/licen ses/by/4.0/.

\section{References}

Almond, Gabriel Abraham, and Sidney Verba. 1974. Civic culture study, 1959-1960. [Computer file]. ICPSR 07201.

Ascoli, Ugo. 1979. I movimenti migratori in Italia. Bologna: Il Mulino.

Atkin, Nicholas, and Frank Tallett. 2003. Priests, Prelates and People: A History of European Catholicism since 1750. London: I.B. Tauris.

Bahr, Howard M. 1970. Aging and Religious Disaffiliation. Social Forces 49: 59. https://doi.org/10.2307/ 2575739.

Barbagli, Marzio. 2018. Alla fine della vita: Morire in Italia e in altri paesi occidentali. Bologna: il Mulino.

Barnes, Samuel H. 1974. Religion and class in Italian electoral behavior. In Electoral behavior: A comparative handbook, ed. Richard Rose. New York: Free Press.

Battelli, Giuseppe. 1992. Clero secolare e società Italiana tra decennio Napoleonico e primo novecento. Alcune ipotesi di rilettura. In Clero e società nell'Italia contemporanea, ed. Mario Rosa, 43-123. Roma: Laterza.

Bellucci, Paolo, and Oliver Heath. 2012. The structure of party-organization linkages and the electoral strength of cleavages in Italy, 1963-2008. British Journal of Political Science 42: 107-135. https:// doi.org/10.1017/S0007123411000226.

Bibby, Reginald W. 1997. Going, Going, Gone: The Impact of Geographical Mobility on Religious Involvement. Review of Religious Research 38: 289. https://doi.org/10.2307/3512192.

Biorcio, Roberto. 2003. Sociologia politica: Partiti, movimenti sociali e partecipazione. Bologna: Il Mulino.

Bonifazi, Corrado, and Frank Heins. 2000. Long-term trends of internal migration in Italy. International Journal of Population Geography 6: 111-131. https://doi.org/10.1002/(SICI)1099-1220(200003/ 04)6:2\%3c111::AID-IJPG172\%3e3.0.CO;2-L.

Bruce, Steve. 2011b. A sociology classic revisited: Religion in Banbury. Sociological Review 59: 201222. https://doi.org/10.1111/j.1467-954X.2011.02003.x.

Bruce, Steve. 2011a. Secularization: In Defence of an Unfashionable Theory. Oxford: Oxford University Press.

Brunetta, Giuseppe. 1991. Il clero in Italia dal 1888 al 1989. Polis V: 423-449.

Burgalassi, Silvano. 1960. La situazione religiosa in Italia. Lettera Di Sociologia Religiosa 1: 9-13.

Burgalassi, Silvano, and Rosario Scarpati. 1966. Religiosità e mutamento sociale in Italia. Lettera Di Sociologia Religiosa II: 2-23.

Burgalassi, Silvano. 1967. Italiani in chiesa, analisi sociologica del comportamento religioso. Brescia: Morcelliana.

Burgalassi, Silvano. 1968. Il comportamento religioso degli italiani. Firenze: Vallecchi Editore.

Carli, Carlo. 1960. La frequenza alla Messa in Italia: alcune note ed un esempio di ricerca nel campo della sociologia religiosa. La Misura dell'opinione pubblica 2: 19-25.

Cartocci, Roberto. 1994. Fra Lega e Chiesa. Bologna: Il Mulino.

Cartocci, Roberto, and Valerio Vanelli. 2015. Geografia dei processi di secolarizzazione. In L'Italia e le sue regioni. L'età repubblicana, ed. Loredana Sciolla and Michele Salvati, III:33-56. Treccani. 
Charpin, Fernand. 1964. Pratique religieuse et formation d'une grande ville. Le geste du baptême et sa signification en sociologie religieuse (Marseille, 1806-1958). Paris: Éditions du Centurion. https:// doi.org/10.3406/asie.1987.899.

Chaves, Mark. 1989. Secularization and Religious Revival: Evidence from U.S. Church Attendance Rates, 1972-1986. Journal for the Scientific Study of Religion 28: 464. https://doi.org/10.2307/ 1386577.

Diamanti, Ilvo, and Luigi Ceccarini. 2007. Catholics and politics after the Christian Democrats: The influential minority. Journal of Modern Italian Studies 12: 37-59. https://doi.org/10.1080/13545 710601132912.

Diotallevi, Luca. 1999. The Territorial Articulation of Secularization in Italy: Social Modernization, Religious Modernization. Archives De Sciences Sociales Des Religions 107: 77-108. https://doi.org/ 10.3406/assr.1999.1164.

Dobbelaere, Karel. 2004. Religion in Modernity. In Patterns and Processes of Religious Change in Modern Industrial Societies: Europe and the United States, ed. Alasdair Crockett and Richard O'Leary, 139-164. The Edwin Mellen Press.

Doxa. 1956. Bollettino Doxa X: 123-131.

Doxa. 1962. Bollettino Doxa XVI: 49-63.

Doxa. 1973. Bollettino Doxa XXVII: 239-259.

Ellison, Christopher G. 1992. Are Religious People Nice People? Evidence from the National Survey of Black Americans. Social Forces 71: 411-430. https://doi.org/10.1093/sf/71.2.411.

Faenza, Liliano. 1959. Comunismo e Cattolicesimo in una parrocchia di campagna. Milano: Feltrinelli.

Finke, Roger, and Rodney Stark. 1992. The Churching of America 1776-1990: Winners and Losers in our religious economy. New Brunswick: Rutgers University Press.

Galli, Giorgio. 1968. Il comportamento elettorale in Italia. Bologna: Il Mulino.

Gamerro, Renzo. 1960. I movimenti migratori nella diocesi d'Ivrea. Lettera Di Sociologia Religiosa 2: $16-23$.

Garelli, Franco. 1996. Forza della religione e debolezza della fede. Bologna: Il Mulino.

Gershuny, Jonathan. 2003. Changing times: Work and leisure in postindustrial society. New York: Oxford University Press.

Giacinto, Enrico. 1995. La sindacalizzazione. In Cesos, Rapporto 1993-94, ed. Guido Baglioni, Serafino Negrelli, and Domenico Paparella, 82-95. Roma: Edizioni Lavoro.

Gourdon, Vincent. 2006. Les pratiques du baptême à Paris et à Rome au XIX e siècle. Popolazione $e$ Storia 2: 19-60.

Grumelli, Antonio. 1965. Religious Behavior of Migrants. The International Migration Digest 2: 158-164.

Guasco, Maurilio. 1986. La formazione del clero: I seminari. In Storia d'Italia, Annali 9, ed. Giorgio Chittolini and Giovanni Miccoli, 631-715. Torino: Einaudi.

Guasco, Maurilio. 1997. Storia del clero in Italia dall'ottocento a oggi. Roma: Laterza.

Hadaway, C. Kirk, and Penny Long Marler. 2005. How many Americans attend worship each week? An alternative approach to measurement. Journal for the Scientific Study of Religion 44. Wiley Online Library: 307-322.

Hadaway, C. Kirk, Penny Long Marler, and Mark Chaves. 1993. What the Polls Don't Show: A Closer Look at U.S. Church Attendance. American Sociological Review 58: 741. https://doi.org/10.2307/ 2095948.

Horowitz, Daniel L. 1963. The Italian Labor Movement. California: Harvard University Press.

Hout, Michael, and Andrew M. Greeley. 1987. The Center Doesn't Hold: Church Attendance in the United States, 1940-1984. American Sociological Review 52: 325. https://doi.org/10.2307/2095353.

Iannaccone, Laurence R. 1991. The Consequences of Religious Market Structure: Adam Smith and the Economics of Religion. Rationality and Society 3: 156-177. https://doi.org/10.1177/1043463191 003002002 .

Ignazi, Piero, and E. Spencer Wellhofer. 2013. Votes and Votive Candles: Modernization, Secularization, Vatican II, and the Decline of Religious Voting in Italy: 1953-1992. Comparative Political Studies 46: 31-62. https://doi.org/10.1177/0010414012453030.

Introvigne, Massimo, and Rodney Stark. 2005. Religious Competition and Revival in Italy: Exploring European Exceptionalism. Interdisciplinary Journal of Research on Religion 1: Article 5.

Jagodzinski, Wolfgang, and Karel Dobbelaere. 1995. Secularization and Church Religiosity. In The Impact of Values, ed. Jan W. Van Deth and Elinor Scarbrough, 76-119. Oxford: Oxford University Press. 
Jitodai, Ted T. 1964. Migrant Status and Church Attendance. Social Forces 43: 241-248. https://doi.org/ $10.2307 / 2574337$

Kan, Man Yee, and Stephen Pudney. 2008. Measurement Error in Stylized and Diary Data on Time Use. Sociological Methodology 38. Wiley Online Library: 101-132. https://doi.org/10.1111/j.1467-9531. 2008.00197.x.

Kertzer, David I. 1980. Comrades and Christians: Religions and political struggle in Communist Italy. London: Cambridge University Press.

Lipset, Seymour Martin, and Stein Rokkan. 1967. Cleavage Sturctures, Party systems and Voter Alignments: An Introduction. In Party Systems and Voter Alignments: Cross-National Perspectives, ed. Seymour Martin Lipset and Stein Rokkan, 1-64. New Work.

Mannheimer, Renato, and Giacomo Sani. 1987. Il mercato elettorale: Identikit dell'elettore italiano. Bologna: Il Mulino.

Marchisio, Roberto, and Maurizio Pisati. 1999. Belonging without believing: Catholics in contemporary Italy. Journal of Modern Italian Studies 4: 236-255. https://doi.org/10.1080/13545719908455008.

Martin, David. 2005. On Secularization: Towards a Revised General Theory. Aldershot: Ashgate Publishing Limited.

Menozzi, Daniele. 1986. Tra riforma e restaurazione. Dalla crisi della società cristiana al mito della cristianità medioevale (1758-1848). In Storia d'Italia, Annali 9: La Chiesa e il potere politico dal Medioevo all'età contemporanea, ed. Giorgio Chittolini and Giovanni Miccoli, 769-806. Torino: Einaudi.

Menozzi, Daniele. 1992. I vescovi dalla rivoluzione all'unità. Tra impegno politico e preoccupazioni sociali. In Clero e società nell'Italia contemporanea, ed. Mario Rosa, 125-179. Roma: Laterza.

Menozzi, Daniele. 1993. La Chiesa Cattolica e la secolarizzazione.

Minello, Alessandra, Gianpiero Dalla-Zuanna, and Guido Alfani. 2017. First signs of transition: The parallel decline of early baptism and early mortality in the province of Padua (northeast Italy), 18161870. Demographic Research 36: 759-802. https://doi.org/10.4054/DemRes.2017.36.27.

Pollard, John Francis. 2008. Catholicism in Modern Italy: Religion, Society and Politics since 1861. New Work: Routldge.

Presser, Stanley, and Linda Stinson. 1998. Data collection mode and social desirability bias in selfreported religious attendance. American Sociological Review 63: 137-145. https://doi.org/10.2307/ 2657486.

Requena, Miguel, and Mikolaj Stanek. 2013. Secularization in Poland and Spain after the democratic transition: A cohort analysis. International Sociology 28: 84-101. https://doi.org/10.1177/02685 80912466551.

Ricolfi, Luca. 1988. Il processo di secolarizzazione nell'Italia del dopoguerra: Un profilo empirico. Rassegna Italiana Di Sociologia 1: 37-87.

Rocca, Giancarlo. 1992. Istituti religiosi in Italia tra Otto e Novecento. In Clero e società nell'Italia contemporanea, ed. Mario Rosa, 212-215. Roma: Laterza.

Romagnoli, Guido, ed. 1980. La sindacalizzazione tra ideologia e pratica: il caso italiano 1950/1977, volume 1. Roma: Dalla Romana Editrice.

Romagnoli, Guido, and Maurizio Rossi. 1980. La sindacalizzazione in Italia, tra ciclo economico, conflitto e facilitazione istituzionali. In La sindacalizzazione tra ideologia e pratica: il caso italiano 1950/1977, volume 1, ed. Guido Romagnoli, 45-94. Roma: Dalla Romana Editrice.

Rossi, Maurizio, and Ettore Scappini. 2012. How should Mass attendance be measured? An Italian case study. Quality \& Quantity 46: 1897-1916. https://doi.org/10.1007/s11135-011-9655-2.

Rossi, Maurizio, and Ettore Scappini. 2014. Church Attendance, Problems of Measurement, and Interpreting Indicators: A Study of Religious Practice in the United States, 1975-2010. Journal for the Scientific Study of Religion 53: 249-267. https://doi.org/10.1111/jssr.12115.

Rossi, Maurizio, and Ettore Scappini. 2016. The Dynamics of Religious Practice in Spain from the Mid19th Century to 2010. Journal for the Scientific Study of Religion 55: 579-596. https://doi.org/10. 1111 /jssr. 12280 .

Ruggieri, Giuseppe. 2011. La condanna dei comunisti del 1949. www.treccani.it/enciclopedia/la-conda nna-dei-comunisti-del-1949_(Cristiani-d'Italia).

Sani, Giacomo. 2006. Il mercato elettorale rivisitato. Rivista Italiana Di Scienza Politica 36: 351-362. https://doi.org/10.1426/23351.

Sani, Giacomo, and Paolo Segatti. 2002. Fratture sociali, orientamenti politici e voto: Ieri e oggi. In Maggioritario, finalmente? La transizione elettorale 1994-2001, ed. Roberto D'Alimonte and Stefani Bartolini, 249-281. Bologna: Il Mulino. 
Scappini, Ettore. 2018. Problems in Measuring Diachronic Religious Behavior, or Using Indicators to 'Make a Virtue of Necessity': The Case of the Netherlands (1975-2005). Review of Religious Research 60: 133-151. https://doi.org/10.1007/s13644-017-0314-5.

Scappini, Ettore. 2021. Calibrating Questionnaires with Weekly Diaries: An Application in Religious Behavior, Netherlands 1975 to 2005. Sociological Methodology 51: 166-187. https://doi.org/10. 1177/0081175020927438.

Segatti, Paolo. 1999. Religiosità e territorio nel voto alla Democrazia Cristiana dal 1948 al 1992. Polis XIII 45-65. https://doi.org/10.1424/2690.

Stark, Rodney, and William Sims Bainbridge. 1980. Towards a Theory of Religion: Religious Commitment. Journal for the Scientific Study of Religion 19: 114-128. https://doi.org/10.2307/1386246.

Stark, Rodney, and Laurence R. Iannaccone. 1994. A Supply-Side Reinterpretation of the "Secularization" of Europe. Journal for the Scientific Study of Religion 33: 230. https://doi.org/10.2307/13866 88.

Stolzenberg, Ross M., Mary Blair-Loy, and Linda J. Waite. 1995. Religious Participation in Early Adulthood: Age and Family Life Cycle Effects on Church Membership. American Sociological Review 60: 84. https://doi.org/10.2307/2096347.

Tannenbaum, Edward R. 1972. Fascism in Italy: Society and Culture, 1922-1945. London: Allen Lane.

Tarrow, Sidney. 1989. Democracy and disorder: Protest and Politics in Italy, 1965-1975. Oxford: Oxford University Press.

Thomassen, Jacques. 2005. The European voter: A comparative study of modern democracies. Oxford: Oxford University Press. https://doi.org/10.1093/0199273219.001.0001.

Verucci, Guido. 1976. Chiesa e società nell'Italia della restaurazione (1814-1830). Rivista di Storia della Chiesa in Italia XX: 25-72.

Vezzoni, Cristiano, and Ferruccio Biolcati-Rinaldi. 2015. Church attendance and religious change in Italy, 1968-2010: A multilevel analysis of pooled datasets. Journal for the Scientific Study of Religion 54: 100-118. https://doi.org/10.1111/jssr.12173.

Voas, David. 2009. The Rise and Fall of Fuzzy Fidelity in Europe. European Sociological Review 25: 155-168. https://doi.org/10.1093/esr/jcn044.

Voas, David, and Mark Chaves. 2016. Is the United States a Counterexample to the Secularization Thesis? American Journal of Sociology 121: 1517-1556. https://doi.org/10.1086/684202.

Voas, David, and Alasdair Crockett. 2005. Religion in Britain: Neither Believing nor Belonging. Sociology 39: 11-28. https://doi.org/10.1177/0038038505048998.

Wallis, Roy, and Steve Bruce. 1992. Secularization: The Orthodox Model. In Religion and Modernization: Sociologists and Historian Debate the Secularization Thesis, ed. Steve Bruce, 2001st ed., 8-30. Oxford: Oxford University Press.

Welch, Michael R., and John Baltzell. 1984. Geographic Mobility, Social Integration, and Church Attendance. Journal for the Scientific Study of Religion 23: 75-91.

Wilson, Bryan R. 1976. Contemporary transformations of religion. London: Oxford University Press.

Wolf, Christof. 2008. How Secularized is Germany? Cohort and Comparative Perspectives. Social Compass 55: 111-126. https://doi.org/10.1177/0037768608089733.

Zunino, Pier Giorgio. 1975. La questione cattolica nella sinistra italiana (1919-1939). Bologna: Il Mulino.

Publisher's Note Springer Nature remains neutral with regard to jurisdictional claims in published maps and institutional affiliations.

\section{Authors and Affiliations}

\section{Ettore Scappini ${ }^{1}$}

Ettore Scappini

ettore.scappini@unibo.it

1 Department of Education Studies, University of Bologna, via Filippo Re, 6, 40126 Bologna, Italy 